\title{
HUBUNGAN SIZE TERHADAP TAX COMPLIANCE YANG DI MODERASI OLEH AUDIT KAP
}

\author{
Subadriyah \\ Universitas Islam Nahdlatul Ulama Jepara \\ subadriyah@unisnu.ac.id
}

\begin{abstract}
Taxes play an important role in the Indonesian economy because taxes are the largest source of state revenue. This portion of tax revenue tends to be greater than non-tax revenue. This study aims to see the effect of company size on tax compliance (taxpayers) as moderated by the KAP audit. This research is a secondary quantitative research. The population that was taken was the furniture company in Jepara. By using purposive sampling technique, 35 companies were selected as samples. Data obtained from the financial statements of furniture companies in Jepara. The analytical method used was a simple linear regression analysis and the Moderated Regression Analysis (MRA) method. Tthe results show that company size has an effect on tax compliance. This means that large companies have stability in generating profits are compliant with taxes and report taxes honestly. Meanwhile, the audit board of financial statements is not a moderating variable. Whether there is a KAP audit or not does not affect the size of the tax supervision (tax compliance)
\end{abstract}

Keywords: Size; Tax Compliance; KAP Audits.

\begin{abstract}
Abstrak
Pajak berperan penting dalam perekonomian Indonesia karena pajak sebagai sumber penerimaan negara paling besar. Porsi penerimaan pajak ini cenderung lebih besar dibandingkan dengan penerimaan non pajak. Penelitian ini bertujuan untuk mengetahui size (ukuran perusahaan) terhadap tax compliance (kepatuhan wajib pajak) yang dimoderasi oleh audit KAP. Penelitian ini merupakan penelitian kuantitatif sekunder. Populasi yang diambil yaitu perusahan meubel yang ada di Jepara dengan teknik pengambilan sampel purposive sampling. Sehingga sampel penelitian menjadi 35 perusahaan. Data diperoleh dari laporan keuangan perusahaan meubel yang ada di Jepara. Metode analisis yang digunakan adalah analisis regresi linier sederhana dan metode Moderated Regression Analysis (MRA). Penelitian ini menunjukkan hasil bahwa size berpengaruh terhadap tax compliance. Hal ini berarti perusahaan yang besar memiliki kestabilan dalam menghasilkan laba dimana patuh terhadap pajak dan melaporkan pajak secara jujur. Sedangkan, dewan audit atas laporan keuangan bukan merupakan variabel moderasi. Ada tidaknya audit KAP tidak mempengaruhi besar kecilnya kepatuhan pajak (tax compliance).
\end{abstract}

Kata Kunci: Size; Tax Compliance; Audit KAP 


\section{PENDAHULUAN}

Salah satu sumber yang berperan dalam perekonomian Indonesia adalah pajak. Pajak sebagai sumber penerimaan negara paling besar. Porsi penerimaan pajak ini cenderung lebih besar jika dibandingkan dengan penerimaan bukan pajak. Sampai tahun 2018, pajak mampu menyumbang lebih dari $75 \%$ pendapatan negara. Sebagai sumber negara, dari tahun ke tahun kontribusi pajak mengalami peningkatan. Sekarang ini pajak menjadi sektor yang paling prioritas sebagai sumber pendanaan pembangunan di berbagai bidang. Akan tetapi, tax ratio (rasio penerimaan pajak) di Indonesia tahun 2018 yaitu sebesar 11,5\%. Pemerintah akan selalu berupaya dalam menaikkan rasio penerimaan pajak secara bertahap dengan melihat kondisi perekonomian Indonesia.

Kinerja penerimaan pajak dipengaruhi oleh adanya tax compliance (kepatuhan wajib pajak). Kepatuhan wajib pajak memegang peranan yang sangat penting dalam keberhasilan pemerintah menentukan besarnya penerimaan dari sektor pajak (Husnurrosyidah, 2016). Akan tetapi, per akhir 2019 tingkat kepatuhan menunjukkan rasio $73 \%$. Rasio tersebut masih di bawah target yang ditetapkan pada awal tahun lalu yaitu sebanyak $80 \%$. Hal ini berarti kesadaran wajib pajak dalam memenuhi kewajiban perpajakannya masih sangat rendah, sehingga kepatuhan wajib pajak (Tax Compliance) di Indonesia masih perlu untuk di perbaiki.

Rendahnya tingkat kepatuhan wajib pajak (Tax Compliance) membuat penerimaan negara menjadi tidak maksimal. Hal ini kadang terjadi bukan sebuah kesengajaan melainkan masih minimnya pengetahuan dari wajib pajak (tax payer) dalam menjalankan kewajibannya, (Suyanto, Intansari, \& Endahjati, 2016). Hal tersebut dapat dikategorikan sebagai perlawanan pajak (tax evasion) yang bersifat pasif akibat ketidakpahaman yang mengakibatkan tidak melakukan pelaporan dan pembayaran pajak (Ayu R \& Hastuti, 2009).

Bagi wajib pajak yang sudah mengetahui dan memenuhi ketentuan undangundang perpajakan, tidak mengalami hambatan dalam melakukan kewajibannya. Akan tetapi, masih banyak masyarakat Indonesia, terutama wajib pajak orang pribadi (WP OP) baik karyawan maupun pengusaha yang belum mengetahui tentang pelaporan pajak. Berdasarkan catatan pajak.go.id hingga tahun 2015, penduduk Indonesia yang bekerja yaitu 120,8 juta. Namun, wajib pajak orang pribadi (WP OP) yang berusaha menyampaikan surat pemberitahuan tahunan (SPT) hanya sebanyak 10.269.162 WP OP yang terdiri dari 9.431.934 WP OP karyawan dan 837.228 WP OP non karyawan. Hal ini menunjukkan tingkat kepatuhan WP OP (dilihat dari penyampaian SPT) hanya sebesar 63,22\% WP OP karyawan dan 40,75\% WP OP non karyawan. Yang lebih memprihatinkan, dari jumlah WP OP yang menyampaikan SPT hanya 794.418 WP OP bayar. Melihat kondisi tersebut sehingga potensi perpajakan Indonesia sangatlah besar namun belum tergarap secara optimal.

Usaha dalam meningkatkan penerimaan pajak terus dilakukan oleh Direktorat Jenderal Pajak (DJP). Usaha tersebut meliputi ekstensifikasi dan intensifikasi pajak. Reformasi perpajakan pertama dalam upaya peningkatan

* Corresponding author's e-mail: subadriyah@unisnu.ac.id http://openjournal.unpam.ac.id/index.php/JABI 
kepatuhan wajib pajak (Tax Compliance) telah dikerahkan oleh pemerintah sejak tahun 1984 (Fidiana, 2016). Kepatuhan wajib pajak (Tax Compliance) dapat dilihat dari patuh atau tidaknya seorang wajib pajak dalam mendaftrakan dirinya, melaporkan surat pemberitahuan pajak, kepatuhan dalam membayar pajak terutang dan tunggakan pajak.

Usaha memaksimalkan dalam penerimaan pajak ini tidak dapat hanya mengandalkan peran dari dirjen pajak, akan tetapi membutuhkan peran aktif dari wajib pajak itu sendiri. Perubahan system perpajakan menjadi self assessment ini memberikan kepercayaan kepada wajib pajak untuk mendaftar, menghitung, membayar serta melaporkan kewajiban perpajakannya sendiri. Hal inilah yang menjadikan kepatuhan wajib pajak menjadi faktor yang sangat penting dalam mencapai keberhasilan penerimaan pajak.

Ukuran perusahaan (size) merupakan skala yang dapat mengelompokkan perusahaan menjadi perusahaan besar dan perusahaan kecil. Ukuran perusahaan (Size) dapat dilihat dari total asset yang dimiliki oleh perusahaan, nilai pasar saham rata-rata tingkat penjualan, dan jumlah penjualan (Calvin, 2015). Nilai perusahaan semakin besar apabila nilai-nilai dari item tersebut semakin besar pula. Perusahaan yang termasuk dalam kelompok memiliki aset yang besar akan cenderung lebih stabil dan lebih mampu untuk menghasilkan laba apabila dibandingkan dengan perusahaan dengan total aset yang kecil (Dewi \& Noviari, 2017). Terdapat perbedaan dalam kesadaran perpajakan antara wajib pajak besar dan wajib pajak kecil. Di mana wajib pajak yang memiliki ukuran perusahaan besar akan memiliki kesadaran perpajakan yang tinggi bila dibandingkan dengan wajib pajak kecil. Hal ini juga di ikuti dengan jumlah pajak penghasilan yang meningkat sesuai dengan peningkatan laba perusahaan.

Ukuran perusahaan (size) ditunjukkan melalui log total aset, karena ukuran tersebut dinilai lebih stabil bila dibandingkan proksi-proksi yang lainnya dan berkesinambungan antar periode. Perbedaan dalam ukuran perusahaan, kepemilikan, modal, aktivitas usaha, kebijakan manajemen maupun gaya kepemimpinan manajemen akan mempengaruhi kemampuan menghasilkan laba yang diungkapkan. Yujana (2006) menjelaskan bahwa size, leverage, profitabilitas, kelompok perusahaan signifikan dalam mempengaruhi tingkat voluntary disclosure. Pengungkapan laba ini adalah salah satu indikator dari penentuan besarnya jumlah pajak terutang yang selalu menjadi perhatian pengguna laporan laporan keuangan. Semakin besar ukuran perusahaan diharapkan dapat memberikan kontribusi yang tinggi terhadap pemasukan pajak. Selain itu adanya kewajiban audit atas laporan keuangan bagi perusahaan yang mengikuti lelang dari pihak pemerintah, diharapkan akan meningkatkan Tax Compliance karena laporan keuangan perusahaan telah diaudit oleh pihak eksternal.

Penelitian yang dilakukan di Medan Timur memberikan hasil bahwa secara simultan karakteristik perusahaan mempengaruhi tingkat kepatuhan WP, namun secara parsial ukuran perusahaan tidak berpengaruh terhadap kepatuhan WP (Hani \& Lubis, 2010). Praktik penghindaran pajak dalam suatu perusahaan secara signifikan dapat menurun karena dipengaruhi oleh adanya kelompok perusahaan besar (Dewi \& Noviari, 2017). Semakin besar Size perusahaan maka biaya 
kepatuhan juga akan semakin besar. Hasil minimalisasi biaya kepatuhan pajak diperoleh hasil bahwa kondisi kepatuhan pajak dapat $\mathrm{m}$ encapai tingkat tertinggi pada tingkat $70.15 \%$ (Prasetyo, 2008)

Penelitian ini bertujuan untuk mengetahui pengaruh dari size (ukuran perusahaan) terhadap tax compliance (kepatuhan wajib pajak) yang dimoderasi oleh audit KAP. Adapun kerangka penelitian lihat Gambar 1.

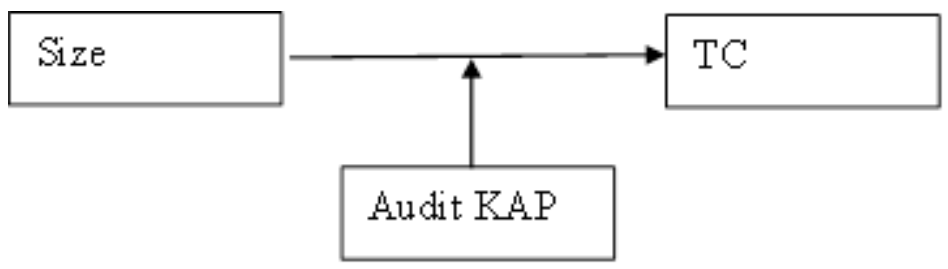

Gambar 1. Kerangka Penelitian

\section{KERANGKA TEORITIS DAN PENGEMBANGAN HIPOTESIS}

\section{Tax Compliance}

Tax Compliance adalah suatu keadaan dari WP dengan memenuhi segala kewajiban dan menjalankan kewajiban membayar pajaknya (Rahman, 2010). Kepatuhan pajak telah digolongkan menjadi dua, yaitu kepatuhan pajak formal dan material. Kepatuhan pajak formal yakni kepatuhan yang berkaitan dengan pemenuhan UU, diantaranya terdaftar memiliki NPWP, tidak mempunyai utang pajak serta melaporkan SPT Masa dan Tahunan secara tepat waktu. Sedangkan kepatuhan pajak material yakni keadaan WP yang secara substantif memenuhi dan menjalankan semua isi UU perpajakan (Hutasoit, 2017). Tax compliance terdapat dua pendekatan yakni pertama rational choice yang mana terjadi karena factor ekonomi seperti tingkat hukuman, tingkat audit serta adanya kemungkinan ditangkap. Kedua sentimental moral yang dipengaruhi oleh factor psikologi.

\section{Ukuran Perusahaan (Size)}

Size merupakan ukuran yang menunjukkan besar kecilnya dari suatu perusahaan yang dinilai dari total asset, jumlah laba, beban pajak, total penjualan, dan lain-lain (Brigram \& Joel, 2009). Size merupakan simbol dari ukuran perusahaan telah menjelaskan bahwa kemudahan aksesibilitas perusahaan besar akan lebih mudah ke dalam pasar modal sedangkan perusahaan kecil tidaklah mudah. Menurut (Kurniasih \& Annisa, 2012) ukuran perusahaan adalah nilai yang menunjukkan besar dan kecilnya suatu perusahaan. Size merupakan skala yang mengukur total aktiva yang dimilki perusahaan. Semakin meningkat total aktiva perusahaan maka tingkat produktifitas akan meningkat pula. Hal tersebut

* Corresponding author's e-mail: subadriyah@unisnu.ac.id 
berdampak pada meningkatnya laba perusahaan yang berpengaruh pada tingkat pembayaran pajak suatu perusahaan.

\section{Audit KAP}

Dipandang dari audit pada sudut objektif, audit akuntan merupakan laporan keuangan dalam suatu organisasi yang memiliki tujuan penentuan pada laporan keuangan tersebut telah tersajikan secara wajar dengan kondisi keuangan dan hasil dari usaha perusahaan (Hasanah \& Putri, 2018). Menurut Messier (2003:8) dalam (Rattu, Saerang, \& Nangoi, 2015) audit (auditing) merupakan suatu proses sistematis memperoleh serta mengevaluasi bukti secara objektif yang berhubungan dengan asersi atas tindakan dan peristiwa ekonomi demi memastikan tingkat kesesuaian antara asersi-asersi tersebut dan menetapkan kriteria serta mengkomunikasikan hasilnya kepada pihak-pihak yang berkepentingan.

Dari pengertian di atas dapat disimpulkan bahwa auditor yang mempunyai kemampuan indepedensi dan kompentensi sebagai ukuran kualitas audit, maka auditor dapat memberikan informasi yang nyata (actual).

\section{Penelitian Terdahulu}

Penelitian yang dilakukan di Medan Timur memberikan hasil bahwa secara simultan. karakteristik perusahaan mempengaruhi tingkat kepatuhan wajib pajak, namun secara parsial ukuran perusahaan tidak berpengaruh signifikan terhadap kepatuhan wajib pajak (Hani \& Lubis, 2010). Perusahaan yang dikelompokkan kedalam ukuran yang besar dapat mempengaruhi secara signifikan menurunnya praktik penghindaran pajak yang terjadi dalam perusahaan (Dewi \& Noviari, 2017). Semakin besar ukuran suatu perusahaan (Size) maka biaya kepatuhan juga akan semakin besar. Hasil minimalisasi biaya kepatuhan pajak menunjukkan hasil bahwa dapat mencapai tingkat tertinggi pada tingkat 70.15\% (Prasetyo, 2008).

\section{Hipotesis}

Size merupakan skala yang dapat mengelompokkan perusahaan menjadi perusahaan besar dan perusahaan kecil. Ukuran perusahaan (Size) dapat dilihat dari total asset yang dimiliki oleh perusahaan, rata-rata tingkat penjualan, nilai pasar saham dan jumlah penjualan (Calvin, 2015).

Semakin besar ukuran perusahaan diharapkan dapat berkontribusi yang tinggi terhadap pemasukan pajak. Selain itu adanya kewajiban audit atas laporan keuangan bagi perusahaan yang mengikuti lelang dari pihak pemerintah, diharapkan akan meningkatkan Tax Compliance karena laporan keuangan perusahaan telah diaudit oleh pihak eksternal. Semakin besar ukuran perusahaan cenderung memiliki kestabilan dalam menghasilkan laba di mana patuh terhadap

* Corresponding author's e-mail: subadriyah@unisnu.ac.id 
pajak dan melaporkan pajak secara jujur merupakan salah satu demi menghindari sanksi dan perpajakan.

Berdasarkan penelitian yang dilakukan di Medan Timur memberikan hasil bahwa secara simultan karakteristik perusahaan mempengaruhi tingkat kepatuhan WP, namun secara parsial ukuran perusahaan tidak berpengaruh terhadap kepatuhan wajib pajak (Hani \& Lubis, 2010). Perusahaan yang dikelompokkan kedalam ukuran yang besar dapat mempengaruhi secara signifikan menurunnya praktik penghindaran pajak yang terjadi dalam perusahaan (Dewi \& Noviari, 2017). Semakin besar ukuran suatu perusahaan (Size) maka biaya kepatuhan juga akan semakin besar. Hasil minimalisasi biaya kepatuhan pajak menunjukkan hasil bahwa dapat mencapai tingkat tertinggi pada tingkat 70.15\% (Prasetyo, 2008). Maka dapat dirumuskan hipotesis sebagai berikut:

H1: Size berpengaruh signifikan terhadap Tax Compliance

H2: Size yang dimoderasi oleh Audit KAP berpengaruh signifikan terhadap Tax Compliance

\section{METODE RISET}

Penelitian ini merupakan penelitian kuantitatif sekunder. Di mana data penelitian ini diperoleh dari data laporan keuangan perusahaan mebel di Jepara. Penelitian ini akan menganalisis pengaruh hubungan size terhadap tax compliance yang dimoderasi oleh audit KAP.

Populasi dari penelitian ini adalah perusahan meubel yang ada di Jepara sebanyak 176. Teknik pengambilan sampel menggunakan teknik purposive sampling yang didasarkan pada kriteria yaitu berdasarkan omzet yang diperoleh 35 perusahaan sampel. Data yang digunakan untuk menentukan karakteristik perusahaan adalah data sekunder berupa data dari laporan keuangan perusahaanperusahan Meubel yang ada di Jepara. Adapun pengukuran variabel dapat dilihat pada table 1.

Metode analisis yang digunakan adalah analisis regresi linier sederhana. Hal ini didasarkan pada hubungan antara satu variabel dependen dan satu variabel independen. Harapannya dengan uji regresi ini untuk mengetahui pengaruh hubungan size terhadap tax compliance yang dimoderasi oleh audit KAP. Adapun persamaannya yaitu:

$\mathrm{Y}=\alpha+\beta \mathrm{X}+\mathrm{e}$

Uji regresi dilakukan apabila model dalam penelitian ini bebas dari uji asumsi klasik. Selain itu pendekatan analitik untuk mengontrol pengaruh dari variabel pemoderasi menggunakan metode Moderated Regression Analysis (MRA) (Ghozali, 2011). Adapun persamaannya adalah sebagai berikut:

$\mathrm{Yi}=\mathrm{a}+\mathrm{b} 1 \mathrm{Xi}+\mathrm{e}$

* Corresponding author's e-mail: subadriyah@unisnu.ac.id 


$$
\begin{array}{ll}
\mathrm{Yi} & =\mathrm{a}+\mathrm{b} 1 \mathrm{Xi}+\mathrm{b} 2 \mathrm{Zi}+\mathrm{e} \ldots \ldots \ldots \ldots . .(2) \\
\mathrm{Yi} & =\mathrm{a}+\mathrm{b} 1 \mathrm{Xi}+\mathrm{b} 2 \mathrm{Zi}+\mathrm{b} 3 \mathrm{Xi} * \mathrm{Zi}+\mathrm{e} . .(3) \\
& \text { Dimana: } \\
& \mathrm{Yi} \quad: \text { Tax Compliance } \\
& \mathrm{a} \quad: \text { Konstanta } \\
\mathrm{b} & : \text { Koefisien arah pers. penelitian } \\
\mathrm{X} & : \text { Size } \\
\mathrm{Z} & : \text { Jenis variabel moderator } \\
\mathrm{e} & : \text { variabel pengganggu }
\end{array}
$$

Apabila dalam persamaan ke 2 dan 3 tersebut tidak memiliki perbedaan secara signifikan maka $\mathrm{Z}$ bukanlah variabel moderator tetapi sebagai variabel independen.

Tabel 1. Pengukuran Variabel

\begin{tabular}{lll}
\hline Variabel & Pengukuran & Rumus \\
\hline Tax Compliance & $\begin{array}{l}\text { Corporate Tax to Turn } \\
\text { Over Ratio (CTTOR) }\end{array}$ & PPh Terutang \\
& $\begin{array}{l}\text { (KEP-71/PJ/2009) } \\
\text { Total Pendapatan Bruto }\end{array}$ \\
Size & $\begin{array}{l}\text { Laporan Keuangan di } \\
\text { Audit KAP/Tidak }\end{array}$ & $\begin{array}{l}\text { 1 untuk Laporan Keuangan } \\
\text { diaudit dan 0 sebaliknya }\end{array}$ \\
\hline
\end{tabular}

\section{ANALISIS DATA DAN PEMBAHASAN}

\section{Hasil Uji Asumsi Klasik}

Uji asumsi klasik ini adalah pengujian yang dilakukan sebelum melakukan uji regresi linear berganda. Uji regresi linier ini dapat dilakukan apabila sudah terpenuhi semua syarat uji asumsi klasik dengan menggunakan perhitungan statistik parametrik. Berikut hasil pengujiannya.

\section{Uji normalitas}

Tujuan uji normalitas untuk menguji apakah variabel bebas, variabel terikat atau keduanya berdistribusi normal atau tidak. Dalam penelitian ini uji normalitas diperoleh dengan menggunakan uji One's Sample Kolmogorov-Smirnov Test. Apabila nilai sig K-S > 0,05, maka data berdistribusi dengan normal. Hasil uji normalitas dapat dilihat pada tabel 2 .

\section{Tabel 2. Hasil Uji Normalitas}

\begin{tabular}{llll}
\hline Variabel & N & Sig & Keterangan \\
\hline $\begin{array}{l}\text { Unstandardized } \\
\text { Residual }\end{array}$ & 35 & 0,489 & Normal \\
\hline
\end{tabular}

\section{Sumber : Data Primer yang diolah, 2020}

Hasil pengujian tersebut dilihat bahwa nilai probabilitas signifikansinya $0,489>0,05$. Hal ini berarti data berdistribusi dengan normal. sehingga model regresi layak digunakan untuk penelitian. 


\section{Uji Multikolinieritas}

Uji multikolinieritas digunakan untuk mengetahui terdapat tidaknya korelasi antar variabel independen. Uji ini dilakukan dengan melihat nilai VIF dan Tolerance. Asumsinya jika nilai VIF $<10$ dan nilai Tolerance $>0,1$, maka tidak terjadi multikolinieritas. Hasil uji multikolinieritas diperoleh nilai VIF sebesar 1,000 dan nilai Tolerance sebesar 1,000. Sehingga dalam hal ini memenuhi syarat dan tidak terjadi multikolinieritas.

\section{Uji Heteroskedastisitas}

Uji ini memiliki tujuan untuk menguji apakah di dalam suatu model regresi terjadi ketidaksamaan variasi dari residual satu pengamatan ke pengamatan lain. Model regresi yang baik yaitu tidak terjadi heteroskedastisitas. Uji yang digunakan yaitu dengan Uji Grafik Scatterplot dan diperoleh hasil bahwa tidak terdapat pola yang jelas seperti bergelombang, menyebar kemudian menyempit. Titik-titik tersebut menyebar diatas dan dibawah angka 0 pada sumbu Y. Sehingga dapat disimpulkan tidak terjadi heteroskedastisitas.

\section{Uji Autokorelasi}

Ukuran dalam melihat ada atau tidaknya masalah autokorelasi yaitu dengan melihat Durbin Waton. Hasil pengujian diperoleh nilai DW sebesar 1,596. Nilai tersebut lebih besar dari nilai dU yaitu 1,519. Sehingga dalam hal ini tidak terjadi autokorelasi.

\section{Analisis Regresi Sederhana}

Analisis regresi sederhana digunakan untuk mengetahui pengaruh Size terhadap Tax Compliance. Hasil pengujian dapat dilihat pada tabel 3.

Tabel 3. Hasil Analisis Regresi

\begin{tabular}{|c|c|c|c|}
\hline Variabel & Koefisien Regresi & t-hitung & Sig \\
\hline Konstanta & 0,015 & & \\
\hline Size & 0,751 & 6,541 & 0,000 \\
\hline $\begin{array}{ll}\mathrm{R} & : 0,751 \\
\mathrm{R} \text { Square } & : 0,656\end{array}$ & & & \\
\hline
\end{tabular}

Sumber: Data Primer yang diolah, 2020

Berdasarkan hasil analisis regresi diatas, maka dapat disusun persamaan sebagai berikut:

$\mathrm{Y}=0,015+0,751 \mathrm{X} 1$

Hasil persamaan tersebut diperoleh koefisien regresi, dan dapat dijabarkan sebagai berikut: 
Jika variable Size (X1) konstan, maka akan dapat menaikkan variable Tax Compliance (Y) sebesar 0,015. Sedangkan koefisien regresi variable X1 menunjukkan hasil yang positif hal ini berarti variabel Size berpengaruh positif terhadap Tax Compliance dengan koefisien regresi sebesar 0,751. Hal ini menunjukkan jika Size semakin besar, maka akan meningkatkan Tax Compliance.

Berdasarkan table di atas diperoleh nilai t-hitung sebesar 6,541. Selanjutnya mencari t-tabel dengan rumus $\mathrm{df}=\mathrm{n}-\mathrm{k}$. Dengan tingkat signifikansi $(\alpha)=0,05$. Jadi $\mathrm{df}=\mathrm{n}-\mathrm{k}=35-2=33$, maka diperoleh $\mathrm{t}$-tabel sebesar 1,692. Dengan demikian t-hitung $(6,541)>\mathrm{t}$-tabel $(1,692)$ dan nilai signifikansi $0,000<$ 0,05 . Berdasarkan hal tersebut maka dapat disimpulkan bahwa Size berpengaruh positif dan signifikan terhadap Tax Compliance.

\section{Koefisien Determinasi}

Analisis koefisien determinasi digunakan untuk mengetahui tingkat pengaruh atau tingkat kepercayaan terhadap variabel yang dihitung atau untuk mengukur kemampuan variabel independen dalam menerangkan variasi perubahan variabel dependen. Berdasarkan hasil pengujian nilai $R$ Square sebesar 0,656 , dalam hal ini berarti bahwa variabel independen mempunyai pengaruh positif dan signifikan serta dapat menjelaskan variabel Tax Compliance sebesar $65,6 \%$. Sedangkan sisanya 34,4\% dip`engaruhi oleh faktor lain yang tidak disebutkan dalam penelitian ini.

\section{Analisis Regresi MRA}

Pengujian selanjutnya yaitu analisis regresi menggunakan Moderate Regression Analysis (MRA). Adapun hasil pengujiannya dapat diliat pada tabel 4.

Tabel 4. Hasil MRA

\begin{tabular}{ll}
\hline Variabel & Koefisien Regresi \\
\hline Konstanta & 0,244 \\
Size & 0,540 \\
Audit & $-0,792$ \\
M & 0,938 \\
R & 0,796 \\
R Square & 0,634 \\
Sig Size & 0,345 \\
Sig Audit & 0,024 \\
Sig M & 0,208 \\
\hline
\end{tabular}

Sumber : Data yang diolah, 2020

Hasil uji statistik tersebut menunjukkan bahwa variabel interaksi menunjukkan nilai signifikansi 0,208 hal ini lebih dari 0,05, maka dapat disimpulkan bahwa dewan audit atas laporan keuangan bukan merupakan variabel moderasi. Jadi laporan keuangan yang telah diaudit oleh KAP tidak bisa memperkuat pengaruh antara size dengan tax compliance. Ada tidaknya audit KAP tidak mempengaruhi besar kecilnya kepatuhan pajak (tax compliance).

Terdapat perbedaan dalam kesadaran perpajakan antara wajib pajak besar dan wajib pajak kecil. Dimana wajib pajak yang memiliki ukuran perusahaan besar akan memiliki kesadaran perpajakan yang tinggi bila dibandingkan dengan

* Corresponding author's e-mail: subadriyah@unisnu.ac.id 
wajib pajak kecil. Hal ini juga diikuti dengan jumlah pajak penghasilan yang meningkat sesuai dengan peningkatan laba perusahaan. Pengungkapan laba sebagai salah satu indikator penentuan besarnya jumlah pajak terutang selalu menjadi perhatian pengguna laporan laporan keuangan. Semakin besar ukuran perusahaan diharapkan dapat memberikan kontribusi yang tinggi terhadap pemasukan pajak.

Semakin besar ukuran perusahaan cenderung memiliki kestabilan dalam menghasilkan laba dimana kepatuhan terhadap pajak dan melaporkan pajak secara jujur merupakan salah satu cara untuk menghindari sanksi perpajakan. Permasalahan tax compliance ini merupakan permasalahan yang penting, dalam artian apabila tidak adanya kepatuhan maka akan menimbulkan tindakan penghindaran, pelalaian pajak, penyelundupan, yang nantinya akan berimbas pada penurunan penerimaan negara (Soraya \& Suhendar, 2015).

Ukuran perusahaan yang semakin besar maka cash effective tax rate perusahaan akan semakin tinggi sehingga membuat tingkat penghindaran pajak yang semakin turun. Perusahan dalam kategori besar akan menjaga reputasi perusahaan agar tetap baik di mata publik dan pemerintah, hal ini karena akan menjadi sorotan pemerintah sehingga dilakukan perencanaan pajak yang tidak melanggar ketentuan UU perpajakan.

Perusahaan-perusahaan besar akan memperoleh perhatian yang lebih besar dibandingkan perusahaan-perusahaan kecil terkait laba yang diperolehnya. Perusahaan besar sering menarik perhatian fiskus untuk dikenakan pajak sesuai dengan aturan yang ada. Perusahaan besar cenderung lebih tepat waktu dalam pembayaran pajaknya karena laba yang diperolehnya besar. Perusahaan dengan tingkat profitabilitas yang tinggi terbukti dapat mempengaruhi tingkat kepatuhan dalam mematuhi aturan pajak. Hal ini karena profitabilitas dapat menekan perusahaan dalam melaporkan pajaknya secara jujur.

Laporan keuangan yang telah diaudit oleh KAP tidak bisa memperkuat pengaruh antara size dengan tax compliance. Ada tidaknya audit KAP tidak mempengaruhi besar kecilnya kepatuhan pajak (tax compliance).

\section{KESIMPULAN DAN SARAN}

Berdasarkan hasil pembahasan di atas dapat disimpulkan bahwa company size berpengaruh terhadap tax compliance dengan sig $0,000<0,05$. Hal ini berarti semakin besar ukuran perusahaan maka akan memberikan kontribusi yang tinggi terhadap pemasukan pajak, dan perusahaan yang besar memiliki kestabilan dalam menghasilkan laba dimana patuh terhadap pajak dan melaporkan pajak secara jujur. Akan tetapi, variabel interaksi yaitu Audit KAP menunjukkan nilai signifikansi 0,208 hal ini lebih dari 0,05, sehingga, dewan audit atas laporan keuangan bukan merupakan variabel moderasi. Ada tidaknya audit KAP tidak mempengaruhi besar kecilnya kepatuhan pajak (tax compliance).

* Corresponding author's e-mail: subadriyah@unisnu.ac.id 
Saran bagi penelitian selanjutnya yaitu agar menambah variabel independen yang diasumsikan dapat mempengaruhi tingkat kepatuhan wajib pajak.

\section{DAFTAR PUSTAKA}

Ayu R, S. D., \& Hastuti, R. (2009). Persepsi Wajib Pajak: Dampak Pertentangan Diametral Pada Tax Evasion Wajib Pajak Dalam Aspek Kemungkinan Terdeteksinya Kecurangan, Keadilan, Ketepatan Pengalokasian, Teknologi Sistem Perpajakan, dan Kecenderungan Personal. (Studi Wajib Pajak Orang Pribadi. Jurnal Ilmiah Kajian Akuntansi, 1(1), 1-12.

Brigram, F. E., \& Joel, F. H. (2009). Dasar-dasar Manajemen Keuangan Buku 1 (Edisi Kese). Jakarta: Salemba Empat.

Calvin. (2015). Pengaruh Karakter Eksekutif, Komite Audit, Ukuran Perusahaan, Leverage, dan Sales Growth pada Tax Avoidance. Jurnal Akuntansi Universitas Udayana, 10(1), 47-62.

Dewi, N. L. P. P., \& Noviari, N. (2017). Pengaruh Ukuran Perusahaan, Leverage, Profitabilitas dan Corporate Social Responsibility terhadap Penghindaran Pajak ( Tax Avoidance). E-Jurnal Akuntansi Universitas Udayana, 21(1), 830-859.

Fidiana, F. (2016). Kepatuhan Pajak dalam Perspektif Neo Ashabiyah. Ekuitas Jurnal Ekonomi Dan Keuangan, 19(2), 260-275.

Ghozali, I. (2011). Aplikasi Analisis Multivariate dengan Program IBM SPSSS 19 (5th ed.). Semarang: Badan Penerbit Universitas Diponegoro.

Hani, S., \& Lubis, M. R. (2010). Pengaruh Karakteristik Perusahaan terhadap Kepatuhan Wajib Pajak. Jurnal Riset Akuntansi Dan Bisnis, 10(1), 67-82.

Hasanah, A. N., \& Putri, M. S. (2018). Pengaruh Ukuran Perusahaan, Audit Tenure Terhadap Kualitas Audit. Jurnal Akuntansi : Kajian Ilmiah Akuntansi (JAK), 5(1), 11. https://doi.org/10.30656/jak.v5i1.499

Husnurrosyidah. (2016). Pengaruh Tax Amnesty Dan Sanksi Pajak Terhadap Kepatuhan Wajib Pajak di BMT se-Karesidenan Pati. Equilibrium: Jurnal Ekonomi Syariah, 4(2), 211-226. Retrieved from http://jurnal.syntaxliterate.co.id/index.php/syntax-literate/article/view/90/147

Hutasoit, G. (2017). Pengaruh Tax Amnesty Terhadap Kepatuhan Wajib Pajak di Kota Palembang. Seminar Nasional Teknologi Informasi, Bisnis, Dan Desain.

Kurniasih, L., \& Annisa, N. (2012). Pengaruh Corporate Governance terhadap Tax Avoidance. Jurnal Akuntansi \& Auditing, 8, 95 - 189.

Prasetyo, A. (2008). Pengaruh Uniformity dan Kesamaan Persepsi, Serta Ukuran Perusahaan Terhadap Kepatuhan Pajak. Disertasi, FISIP Universitas Indonesia. $\quad$ Retrieved from http://www.vibiznews.com/1new/templateimages/header.gif

Rahman, A. (2010). Panduan Pelaksanaan Administrasi Perpajakan Untuk Karyawan, Pelaku Bisnis dan Perusahaan. Bandung: Nuansa.

Rattu, N. M., Saerang, D. P. E., \& Nangoi, G. (2015). Pengaruh Ukuran 
Perusahaan, Profitabilitas Perusahaan, Solvabilitas Perusahaan Dan Likuiditas Perusahaan Terhadap Penundaan Audit Pada Perusahaan Consumer Goods Yang Terdaftar Di Bursa Efek Indonesia. Jurnal Riset Akuntansi Dan Auditing "Goodwill," 6(1), 50-60. https://doi.org/10.35800/jjs.v6i1.8450

Soraya, I., \& Suhendar, D. (2015). Pengaruh Tingkat Kepatuhan Wajib Pajak Terhadap Penerimaan Pajak Yang Dimoderasi Oleh Intensitas Pemeriksaan Pajak Pada Kantor Pelayanan Pajak Pratama Kuningan. JRKA, 1(1), 36-48.

Suyanto, Intansari, P. P. L. A., \& Endahjati, S. (2016). Tax Amnesty. Jurnal Akuntansi Fakultas Ekonomi Universitas Sarjanawiyata Tamansiswa, 4(2), 9-22.

Yujana, L. H. (2006). Pengaruh Karakteristik Perusahaan, Struktur Kepemilikan, dan Auditor Eksternal, Karakteristik Individu dan Karakteristik Tata Kelola Korporasi terhadap Pengungkapan Sukarela (studi pada perusahaan terbuka di PT. Bursa Efek Jakarta). Disertasi UNDIP. https://doi.org/www.undip.ac.id/admindmb/abstractlalu/374 